Koretsky Serhii,

$\mathrm{PhD}$ (Law Sciences), Associate Professor, Research Institute of the Kiev National University of Culture and Arts, 36, E. Konovalets str., Kyiv, 01601, Ukraine

ORCID: 0000-0001-6465-7712

\title{
THE EUROPEAN UNION: REALIZING THE CULTURAL FUNCTION OF THE STATE
}

The article is devoted to the research of normative legal and organizational and administrative mechanisms that use authorized state institutions in the process of realization of cultural functions of the state, compliance of these mechanisms with the current EU legislation and generally accepted principles of preservation of cultural heritage and progressive development of national culture.

Key words: Culture, Cultural Heritage, European Cultural Policy, Charter of Fundamental Rights of the European Union, International Center for the Study of the Conservation and Restoration of Cultural Property.

\section{Корецький Сергій. Свропейський Союз: реалізація культурної функції} держсави.

Стаття присвячена дослідженню нормативно-правових та організаиійноадміністративних механізмів, які використовують уповноважені державні установи у процесі реалізації культурних функцій держсави, відповідності циих механізмів чинному законодавству СС та загальновизнаним принципам збереження культурної спадщини та прогресивний розвиток національної культури.

Ключові слова: культура, культурна спадщина, Європейська культурна політика, Хартія основних прав Європейського Союзу, Міжнародний центр вивчення збереження та реставраџії культурних иінностей.

Relevance of the research topic. In the context of further globalization of the world and the desire of Ukrainian society to become a full member of the world community, there is an urgent need to explore the basic principles and corresponding normative prescriptions of equal interaction of peoples in all spheres of public life, including the protection of cultural rights of the individual.

Formulation of the problem. The basis of modern European policy in the field of culture is laid down in the Treaty of the EU, signed on 7 February 1992 in Maastricht (Netherlands) between the members of the European Community and entered into force on 1 November 1993 (T. Shy'nkarenko, 2011;. A. Yu. Marty'nov, 2009). 
Art. 167 of the Culture section identifies three main goals of cultural development: 1) to promote the prosperity of national cultures, while at the same time multiplying the world cultural heritage; 2) to encourage contemporary artistic creativity; 3) to deepen international cooperation in the artistic and cultural spheres. Cultural cooperation, backed up by an appropriate legal framework, is recognized as the core of EU activity, a force that serves to «bring the peoples closer together» (3).

Presenting main material. The cornerstone of safeguarding cultural rights is the Charter of Fundamental Rights of the European Union, the observance of which principles and freedoms are binding on the Union under the Treaty of Lisbon. Yes, the Charter stipulates that art and research cannot be restricted (Article 13) and that the EU must respect culture, religions and linguistic diversity (Article 22) (4) Under the Lisbon Treaty, the Union must respect its cultural and linguistic diversity and protect and further enriching Europe's cultural heritage (Article 3 of the Consolidated version of the Treaty on European Union). Article 6 of the Consolidated version of the Treaty on the Functioning of the EU defines the areas of competence of the Union in the cultural sector, in particular to take action to support, coordinate and complement the actions of the Member States in the field of culture (5). That is, cultural policy is the exclusive competence of a particular EU member state, and the EU itself reserves the right to coordinate the actions of the participating countries in the field of cultural policy.

On the path to European integration, Ukraine is successfully using its right to its own vector of cultural development, especially in international cooperation with the EU. Thus, during 2017, with the assistance of the European Commission, a number of short-term (piloting, with the possibility of further extension) and long-term projects were implemented:

EU Creative Bureau Europe Program Bureau operates in Ukraine The EU National Creative Europe Program Bureau is fully operational on the basis of the Ukrainian Center for Cultural Research. With the assistance of the Ministry of Culture, the site of the National Creative Europe Ukraine Bureau was created -http: //creativeeurope.in.ua/.

In 2017, about 70 events were held by the National Bureau of the EU Creative Europe Program in Ukraine with the support of the Ministry of Culture; the project of web-resource database of Ukrainian cultural and creative industries was developed; work has been done to establish cooperation with partners in Ukraine. Yulia Fedov, Head of the EU's Creative Europe National Program Office in Ukraine, held more than 400 personal and remote consultations

The COMUS project has been implemented.

It is a joint project of the Council of Europe and the European Commission Urban-oriented Urban Strategies in Historic Cities. «The project involves a comprehensive interaction of authorities at all levels and local communities to improve 
the existing urban environment of small historic cities, preserve the historic environment and encourage local residents to participate actively in the life of the city. In July 2017, the final project seminar in Ukraine was held in Kyiv. The project managers of three Ukrainian pilot cities - Lutsk, Zhovkva and Pryluk - presented the project implementation results and the portfolio cities created by the project cities.

Conclusion. Ukraine joins Cultural Routes On September 27-29, 2017 in Lucca, Italy, the 7th Annual Council of Europe Cultural Routes Advisory Forum took place «30 Years of the Council of Europe Cultural Routes: Establishing Dialogue and Sustainable Development through European Values and Heritage». The delegation of the Ministry of Culture took part in the event. In 2017, Ukraine acceded to the Enlarged Partial Agreement on Council of Europe Cultural Routes as an observer. A question is currently under consideration.

\section{REFERENCES}

1. T. Shy'nkarenko. Maastry'xts'ky'j dogovir // Polity'chna ency'klopediya. Redkol.: Yu. Levenecz' (golova), Yu. Shapoval (zast. golovy') ta in. - K.: Parlaments'ke vy'davny'cztvo, 2011. - S. 414.

2. A. Yu. Marty'nov. Maastry'xts'ky'j dogovir // Ency'klopediya istoriyi Ukrayiny' : u 10 t. / redkol.: V. A. Smolij (golova) ta in. ; Insty'tut istoriyi Ukrayiny' NAN Ukrayiny'. - K. : Nauk. dumka, 2009. - T. 6 : La - Mi. - S. 410.

3. Klyuchovi problemy' ta perspekty'vy' rozvy'tku kul'tury' v Ukrayini // Anality'chny'j zvit. - K., 2012. - S. 36.

4. Xartiya osnovny'x prav Yevropejs'kogo Soyuzu (Elektron resurs) // Zakonodavstvo Ukrayiny' : (oficz. sajt). - Rezhy'm dostupu: http://zakon.rada.gov.ua/ laws/show/994_524. - nazva z ekranu.

5. Treaty of Lisbon. - http://europa.eu/lisbon_treaty/full_text/index_en.htm 